\title{
FAKTOR-FAKTOR YANG MEMPENGARUHI KANDUNGAN GAS METANA BATUBARA PADA LAPISAN BATUBARA B DAN C YANG DITEMBUS PEMBORAN DI LOKASI AD-01 DAERAH OMBILIN, KOTA SAWAHLUNTO, PROVINSI SUMATERA BARAT
}

\author{
Oleh: \\ Sigit Arso W., David P. Simatupang dan Robert L. Tobing \\ Pusat Sumber Daya Geologi \\ Jalan Soekarno Hatta No. 444, Bandung
}

\section{SARI}

Pemboran di lokasi AD-01 ditemukan lapisan batubara B dan $\mathrm{C}$ yang berdasarkan hasil analisis kandungan gas memiliki kandungan gas metana $(\mathrm{CH} 4) 84,26 \%$ dan $61,38 \%$. Berdasarkan hasil analisis proksimat diketahui batubara Lapisan B memiliki nilai kalori $7.434 \mathrm{kal} / \mathrm{gr}(\mathrm{adb})$, zat terbang 35,18\%, karbon tertambat 55,10\%, abu (Ash) 7,18 \% dan belerang 1,20\% sedangkan batubara Lapisan C memiliki nilai kalori 7.645,5 kal/gr (adb), zat terbang 40,36 \%, karbon tertambat $53,42 \%$, abu $4,02 \%$ dan belerang $4,38 \%$.

Perbedaan kandungan gas metana yang terdapat dalam lapisan batubara B dan C diperkirakan dipengaruhi oleh komponen-komponen yang terdapat dalam batubara hasil analisis proksimat.

Kata Kunci : Zat Terbang, Karbon Tertambat, Abu, Belerang, Gas Metana

\section{ABSTRACT}

Drilling at location AD-01 was found coal Seam $B$ and $C$ are based on test analysis of gas composition is known that methane contains $84.26 \%$ and $61.38 \%$. Based on results of proximate analysis of coal Seam B is known that has calorific value of 7,434 cal/g (adb), Volatile Matter (VM) $35.18 \%$, Fixed Carbon (FC) $55.10 \%$, Ash (Ash) $7.18 \%$ and Sulphur (S) $1.20 \%$, while coal Seam C has a calorific value of 7,645.5 cal/g (adb), Volatile Matter (VM) $40.36 \%$, Fixed Carbon (FC) $53.42 \%$, Ash (Ash) $4.02 \%$ and Sulphur (S) $4.38 \%$.

Differences coal bed methane contained in the coal Seam $B$ and $C$ is estimated to be affected by the components contained in the coal proximate analysis results.

\section{Keyword: Volatile Matter, Fixed Carbon, Ash, Sulphur, Methane}

\section{PENDAHULUAN}

Secara administratif, daerah penelitian termasuk ke dalam wilayah Kota Sawahlunto, Provinsi Sumatera Barat. Lubang bor AD-01 secara geografis berada pada koordinat 1004728,48" Bujur Timur dan 04041,43" Lintang Selatan dengan total kedalaman 451 meter. (Gambar 1)

Pemboran yang dilakukan di lokasi AD01 menemukan dua lapisan batubara yaitu Lapisan B dan C. Kandungan gas metana batubara di Lapisan B dan C memiliki nilai 84,26 $\%$ dan $61,38 \%$.

Berdasarkan hasil analisis proksimat diketahui bahwa batubara Lapisan B memiliki nilai kalori $7.434 \mathrm{kal} / \mathrm{gr}$ (adb), zat terbang 35,18 $\%$, karbon tertambat $55,10 \%$, abu $7,18 \%$ dan belerang 1,20 \% sedangkan batubara Lapisan C memiliki nilai kalori 7645,5 kal/gr (adb), zat terbang $40,36 \%$, karbon tertambat $53,42 \%$, abu
4,02\% dan belerang 4,38 \%.

Perbedaan nilai hasil analisis proksimat pada batubara Lapisan B dan C diperkirakan sebagi penyebab kandungan gas metana batubara Lapisan B lebih besar dibandingkan dengan Lapisan C.

Zat terbang (Volatile Matter) dan belerang (Sulphur) merupakan dua komponen dari sekian banyak komponen yang terkandung dalam batubara. Zat terbang di definisikan sebagai senyawa organik dalam batubara yang dibebaskan pada saat batubara dipanaskan dengan temperatur tertentu. Sedangkan belerang adalah kadar atau jumlah seluruh belerang baik berupa belerang sulfat, belerang pirit, maupun belerang organik yang terkandung dalam batubara. Kedua komponen tersebut memberikan pengaruh terhadap kualitas batubara semakin kecil kadar kedua komponen tersebut maka semakin bagus kualitas batubara 


\section{MAKALAH ILMIAH}

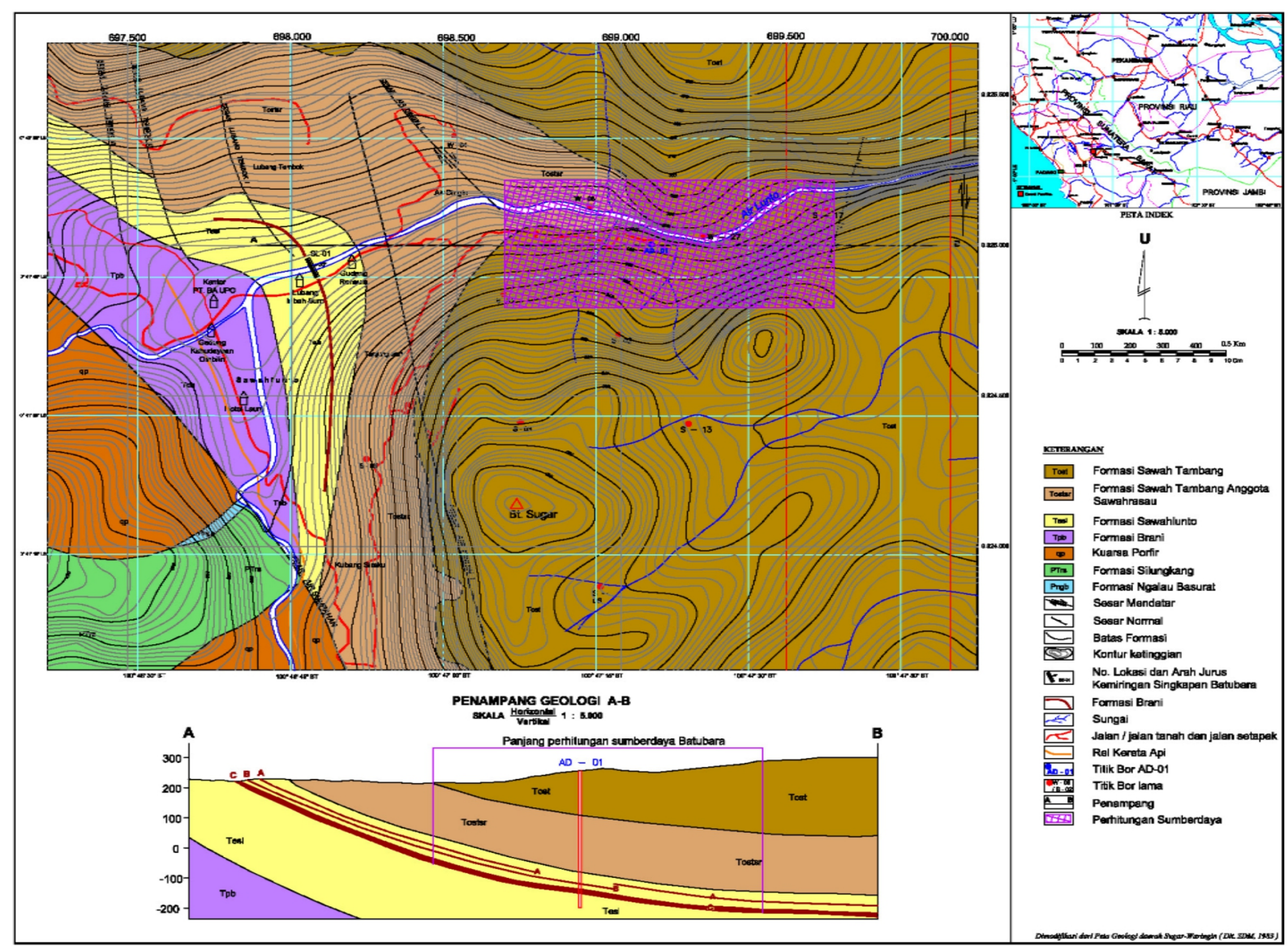

Gambar 1. Peta geologi dan lokasi pemboran AD-01 di daerah penelitian (Tim Pemboran PSDG, 2009)

de m i k i a p p I a s e b a I i kn y a (http://febriantara.wordpress.com/2009/03/18/b atubara/).

Abu (Ash) merupakan residu yang tersisa dari hasil pembakaran batubara pada kondisi tertentu dan umumnya terdiri dari komponen oksida dan sulfat. (Given and Yarzab, 1978; Elliott, 1981 dan Speight, 2005). Sedangkan karbon tertambat (Fixed Carbon) adalah jumlah karbon yang terkandung dalam batubara. (Speight, 2005)

Selain itu batubara juga memiliki kandungan gas, Salah satu gas yang terdapat dalam batubara adalah metana. Menurut Wikipedia metana adalah hidrokarbon paling sederhana yang berbentuk gas dengan rumus kima $\mathrm{CH} 4$. Keberadaan metana di alam diantaranya terdapat di tumpukan sampah, kotoran hewan, batubara dan lain sebagainya. Gas metana batubara merupakan salah satu sumber energi alternatif selain minyak bumi yang dapat dimanfaatkan sebagai bahan bakar.

Penelitian ini bertujuan untuk mengetahui faktor-faktor yang mempengaruhi kandungan gas metana batubara pada lapisan batubara B dan C di lokasi pemboran AD-01 Daerah Ombilin, Kota Sawalunto, Provinsi Sumatera Barat.

\section{GEOLOGI}

Daerah penelitian ditinjau dari segi morfologi terdiri dari Satuan Perbukitan Berlereng Landai dan Satuan Perbukitan Berlereng Terjal. Satuan Perbukitan Berlereng Landai terdiri dari batuan sedimen dari Formasi Brani, Formasi Sawahlunto, Formasi Sawahtambang Anggota Rasau dan sedikit batuan berumur Pra Tersier. Satuan Perbukitan Berlereng Terjal disusun batuan sedimen dari Formasi Brani dan Formasi Sawahtambang Anggota Rasau.

Geologi daerah penelitian termasuk dalam Cekungan Ombilin. Menurut Koning (1985), Cekungan Ombilin terletak pada bagian tengah jalur Pegunungan Barisan yang terbentuk pada 


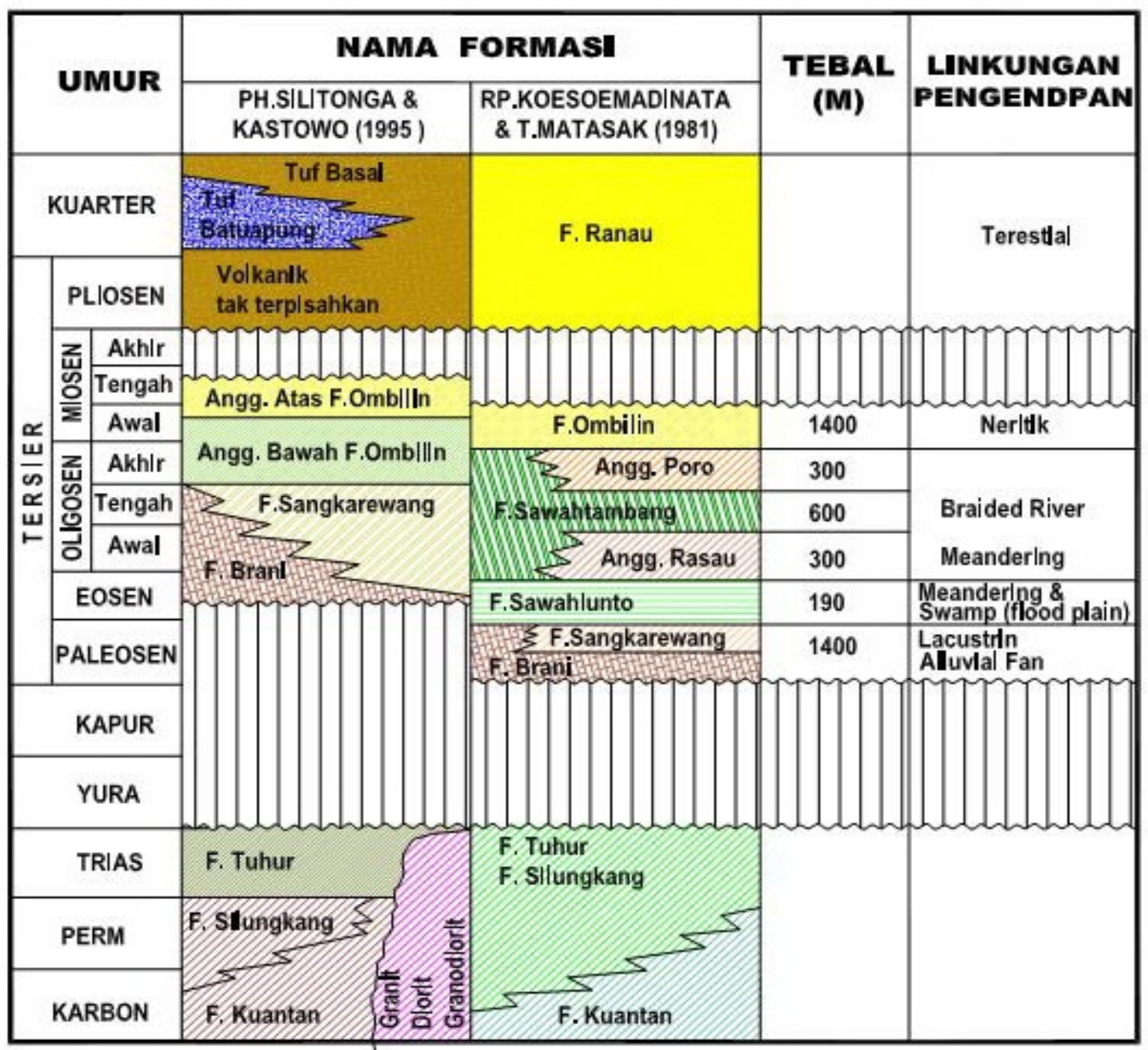

Gambar 2. Kolom stratigrafi Daerah Ombilin

Awal Tersier dan mengandung batuan sedimen yang mencapai ketebalan $4.600 \mathrm{~m}$ serta diendapkan pada lingkungan darat atau danau sampai laut dangkal (Gambar 2).

Formasi pembawa batubara di Cekungan Ombilin menurut Silitonga dan Kastowo (1995), Anggota Bawah Formasi Ombilin yang berumur Oligo-Miosen, sedangkan menurut Koesoemadinata dan Matasak (1981), Formasi Sawahlunto yang berumur Eosen. (Gambar 2).

\section{SUMBER DATA}

Tulisan ini menggunakan data dari data hasil pemboran batubara di lokasi AD-01 Formasi Ombilin Daerah Ombilin Kota Sawahlunto yang dilakukan oleh tim pemboran Pusat Sumber Daya
Geologi Tahun 2009. Conto batubara diambil dari dua lapisan batubara yaitu Lapisan B dan C dengan ketebalan masing-masing batubara adalah 1,75 dan 13,56 meter. Dari kedua lapisan tersebut diambil sebanyak 18 conto batubara untuk kemudian dilakukan analisis komposisi gas metana batubara dan analsis proksimat dimana 2 conto batubara berasal dari Lapisan B dan 16 conto dari Lapisan $\mathrm{C}$.

\section{HASIL DAN ANALISIS}

Analisis komposisi gas dan proksimat dilakukan di laboratorium Pusat Sumber Daya Geologi menggunakan alat GC (Gas Chromatography) 
dan TGA (Thermographic Analysis) dan bertujuan untuk mengetahui keterdapatan atau kandungan gas yang terdapat dalam batubara baik itu berupa gas metana $(\mathrm{CH} 4)$ maupun gas lainnya seperti $\mathrm{CO} 2, \mathrm{~N} 2, \mathrm{CO}, \mathrm{H} 2$ dan $\mathrm{O} 2$. Sedangkan analisis proksimat bertujuan untuk mengetahui jumlah zat terbang, karbon tertambat, kandungan abu, kadar belerang dan nilai kalori yang terdapat dalam batubara

Berdasarkan hasil analisis komposisi gas terhadap 18 conto batubara menunjukkan bahwa komposisi gas metana batubara yang terdapat di kedua lapisan batubara di lokasi pemboran AD-01 berkisar antara 51,11-85,88\% (Tabel 1) dengan kedalaman batubara terletak antara 369,75371,50 meter untuk Lapisan B dan 380,24-393,80 meter untuk Lapisan C.

Tabel 1 memperlihatkan bahwa berdasarkan hasil analisis kandungan gas yang terdapat dalam batubara diketahui bahwa batubara Lapisan B memiliki kandungan gas metana tertinggi 85,88\% dan Lapisan C 70,49 \%. Dari hasil tersebut diketahui bahwa batubara pada Lapisan B memiliki kandungan gas metana lebih besar dibandingkan dengan Lapisan C yang keterdapatan lapisannya lebih dalam.

Secara teoritis, bahwa semakin dalam keterdapatan batubara maka semakin besar pula kandungan gas metana yang terdapat dalam batubara namun di lokasi pemboran AD-01 menunjukkan hal yang berbeda dimana dengan bertambahnya kedalaman, jumlah kandungan gas metana batubara semakin sedikit.

Berdasarkan Hasil analisis proksimat menunjukkan bahwa kandungan zat terbang untuk batubara Lapisan $B$ yang diwakili oleh conto AD-1/B-1 memiliki nilai 35,18 \% dan untuk Lapisan $\mathrm{C}$ yang diwakili oleh conto AD-1/C-1 dan AD-1/C-2 memiliki nilai 40,36\%. Sedangkan untuk kadar belerang pada batubara Lapisan B diperoleh nilai $1,20 \%$ dan Lapisan C memiliki kisaran nilai 4,38\% (Tabel 2).

Kandungan abu hasil analisis proksimat menunjukkan bahwa batubara Lapisan B yang diwakili oleh conto AD-1/B-1 memiliki nilai 7,18\% dan Lapisan $C$ yang diwakili oleh conto AD-1/C-1 dan AD-1/C-2 memiliki nilai 4,02 \%. Sedangkan jumlah karbon tertambat yang terdapat pada Lapisan B 55,10\% dan Lapisan C 53,42 \%.

Nilai kalori batubara di kedua lapisan batubara tersebut berkisar antara 7.434 - $7.833 \mathrm{kal} / \mathrm{gr}$ dimana batubara Lapisan B memiliki nilai kalori $7.434 \mathrm{kal} / \mathrm{gr}$ (adb) dan Lapisan C memiliki nilai kalori 7.645,5 kal/gr (adb). Berdasarkan US System diketahui bahwa batubara pada lokasi pemboran AD-01 termasuk kedalam golongan High Volatile Bituminus C-A.

Secara umum, berdasarkan hasil analisis proksimat terhadap conto kedua lapisan batubara di lokasi pemboran AD-01 diketahui bahwa kandungan zat terbang dan belerang pada batubara Lapisan B memiliki nilai yang lebih kecil dibandingkan dengan Lapisan C. Sedangkan kandungan karbon tertambat dan belerang yang terdapat pada batubara Lapisan B memiliki nilai yang lebih besar dibandingkan dengan Lapisan C.

Hasil analisis komposisi gas dari GC (Gas Chromatography) menunjukkan bahwa nilai komposisi gas metana terbesar $85,88 \%$ terdapat pada canister nomor 3 , Lapisan $B$ dan terendah $51,11 \%$ pada canister nomor 19 Lapisan C (Tabel 1), dengan rata-rata $84,26 \%$ metana pada Lapisan B dan 61,38\% pada lapisan C (Gambar 3). Berdasarkan hasil tersebut diketahui bahwa rata-rata kandungan gas metana batubara pada batubara Lapisan B memiliki nilai yang lebih besar dibandingkan dengan Lapisan $\mathrm{C}$.

Berdasarkan hasil analisis kandungan gas dan proksimat pada batubara Lapisan B dan C di lokasi pemboran AD-01 dapat diketahui untuk batubara Lapisan B memiliki kandungan gas metana batubara $(\mathrm{CH} 4)$, karbon tertambat dan abu yang lebih besar serta kandungan zat terbang dan belerang yang lebih kecil dibandingkan dengan batubara Lapisan C.

Gambar 3 memperlihatkan untuk batubara Lapisan B yang dengan kedalaman 369,75 371,50 meter memiliki kandungan gas metana $84,26 \%$ sedangkan batubara Lapisan C dengan kedalaman 380,24 393,80 meter memiliki kandungan gas metana 61,38. Apabila dibandingkan kedua lapisan batubara di lokasi pemboran AD-01 terlihat jelas bahwa batubara Lapisan $C$ yang dengan keterdapatan dan tebal batubara yang lebih dalam dan tebal memiliki jumlah kandungan gas metana yang lebih sedikit dari batubara Lapisan B.

Hal ini diperkirakan dari adanya faktor hasil analisis proksimat yang menunjukkan perbedaan nilai antara batubara Lapisan B dan C di lokasi pemboran AD-01

\section{PEMBAHASAN}

Secara umum batubara Lapisan $\mathrm{C}$ relatif memiliki lapisan yang lebih tebal bila dibandingkan dengan batubara Lapisan B. Batubara Lapisan C cenderung memiliki kualitas batubara yang lebih baik dibandingkan dengan batubara Lapisan B.

Secara megaskospis, batubara di daerah penelitian berwarna hitam, keras, kilap kusam-agak terang dengan kualitas batubara cukup baik yang menunjukkan tingginya kalori batubara dari daerah ini. (Tim Pemboran PSDG, 2009)

Batubara Lapisan B dan C merupakan target utama untuk dilakukan analisis komposisi gas metana batubara di lubang bor AD-01 daerah 
Tabel 1.

Komposisi gas pada lapisan batubara B dan C (Tim Pemboran PSDG, 2009)

\begin{tabular}{|c|c|c|c|c|c|c|c|c|}
\hline \multirow{2}{*}{$\begin{array}{c}\text { Canister } \\
\text { No. }\end{array}$} & Lap. & \multicolumn{7}{|c|}{ Komposisi Gas (\%) } \\
\cline { 3 - 9 } & Batuara & $\mathbf{H}_{\mathbf{2}}$ & $\mathbf{O}_{\mathbf{2}}$ & $\mathbf{N}_{\mathbf{2}}$ & $\mathbf{C H}_{\mathbf{4}}$ & $\mathbf{C O}$ & $\mathbf{C O}_{\mathbf{2}}$ & Total \\
\hline 2 & $\mathrm{~B}$ & 0 & 1.1439 & 7.3598 & 82.6521 & 0 & 8.8442 & 100 \\
\hline 3 & $\mathrm{~B}$ & 0 & 1.9746 & 8.8798 & 85.8761 & 0 & 3.2695 & 100 \\
\hline 7 & $\mathrm{C}$ & 0 & 4.2547 & 15.4192 & 58.1291 & 0 & 22.1970 & 100 \\
\hline 6 & $\mathrm{C}$ & 0 & 6.1893 & 11.1048 & 64.3880 & 0 & 18.3179 & 100 \\
\hline 5 & $\mathrm{C}$ & 0 & 4.8605 & 12.1380 & 68.2306 & 0 & 14.7709 & 100 \\
\hline 4 & $\mathrm{C}$ & 0 & 4.9639 & 15.1152 & 52.1285 & 0 & 27.7924 & 100 \\
\hline 12 & $\mathrm{C}$ & 0 & 4.8056 & 8.2268 & 70.4935 & 0 & 16.4741 & 100 \\
\hline 11 & $\mathrm{C}$ & 0 & 3.9973 & 5.5772 & 67.9140 & 0 & 22.5115 & 100 \\
\hline 10 & $\mathrm{C}$ & 0 & 5.2682 & 8.0370 & 67.3334 & 0 & 19.3613 & 100 \\
\hline 9 & $\mathrm{C}$ & 0 & 4.8096 & 10.3739 & 61.9374 & 0 & 22.8791 & 100 \\
\hline 8 & $\mathrm{C}$ & 0 & 0.5880 & 1.4709 & 63.1029 & 3.6589 & 31.1792 & 100 \\
\hline 16 & $\mathrm{C}$ & 0 & 2.4659 & 5.9026 & 68.6853 & 0 & 22.9462 & 100 \\
\hline 15 & $\mathrm{C}$ & 0 & 5.7402 & 17.0762 & 54.0859 & 0 & 23.0977 & 100 \\
\hline 14 & $\mathrm{C}$ & 0 & 3.7713 & 9.1222 & 51.9092 & 0 & 35.1973 & 100 \\
\hline 13 & $\mathrm{C}$ & 0 & 3.2379 & 6.7656 & 58.0157 & 0 & 31.9808 & 100 \\
\hline 18 & $\mathrm{C}$ & 0 & 2.5766 & 4.8122 & 62.7249 & 0 & 29.8862 & 100 \\
\hline 17 & $\mathrm{C}$ & 0 & 5.9458 & 8.2784 & 61.8453 & 0 & 23.9304 & 100 \\
\hline 19 & $\mathrm{C}$ & 0 & 6.3061 & 11.0928 & 51.1126 & 0 & 31.4885 & 100 \\
\hline
\end{tabular}

Tabel 2.

Analisis proksimat pada batubara Lapisan B dan C (Tim Pemboran PSDG, 2009)

\begin{tabular}{||l|c|c|c|c|c||}
\hline \hline \multirow{2}{*}{ Jenis Analisis } & \multirow{2}{*}{ Unit } & \multirow{2}{*}{ Basis } & \multicolumn{3}{|c||}{ Kode Conto Batubara } \\
\cline { 4 - 6 } & & & $\mathrm{AD}-1 / \mathrm{B}-1$ & $\mathrm{AD}-1 / \mathrm{C}-1$ & $\mathrm{AD}-1 / \mathrm{C}-2$ \\
\hline Zat Terbang & $\%$ & $\mathrm{adb}$ & 35,18 & 41,97 & 38,75 \\
\hline Karbon Tertambat & $\%$ & $\mathrm{adb}$ & 55,10 & 50,61 & 56,23 \\
\hline Abu & $\%$ & $\mathrm{adb}$ & 7,18 & 5,32 & 2,71 \\
\hline Belerang & $\%$ & $\mathrm{adb}$ & 1,20 & 4,82 & 3,94 \\
\hline Nilai Kalori & $\mathrm{kal} / \mathrm{gr}$ & $\mathrm{adb}$ & 7.434 & 7.458 & 7.833 \\
\hline
\end{tabular}




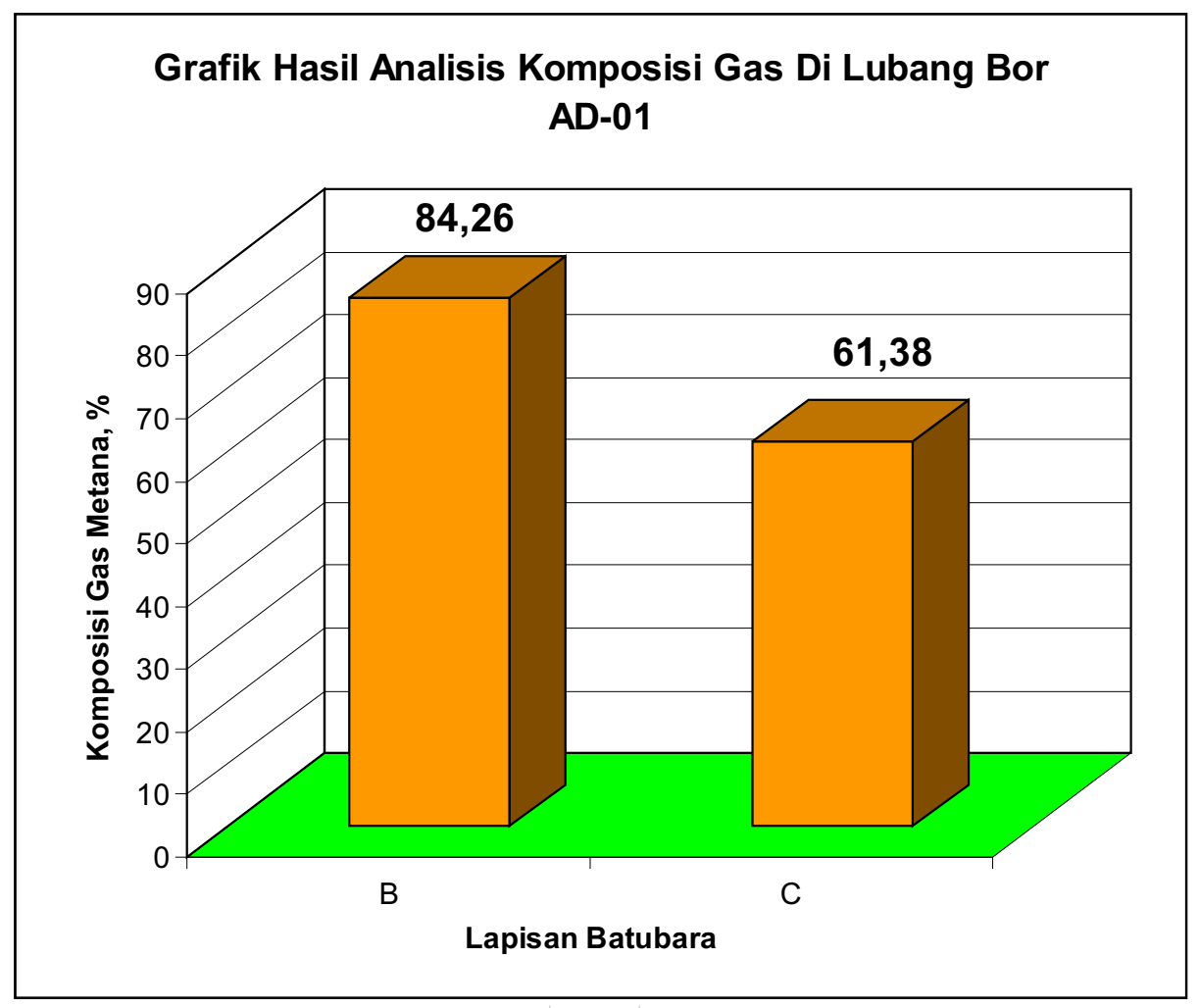

Gambar 3. Grafik hasil analisis komposisi gas metana batubara Lapisan B dan C

Ombilin.

Menurut Rice (1993, dalam Flores 2008) bahwa gas metana batubara (Coal Bed Methane) terdiri 88-98\% gas metana $(\mathrm{CH} 4)$ yang dihasilkan oleh batubara dalam jumlah yang cukup (kisaran 100$300 \mathrm{~m} 3 / \mathrm{g}$ ) selama proses pembentukan batubara dengan sedikit kandungan $\mathrm{CO} 2$ dan N2. Berdasarkan hasil penelitian, Lapisan B dan C rata-rata memiliki $84,26 \%$ dan $61,38 \%$ komposisi gas metana, dengan komposisi N2 yang berkisar antara 4,81-17,08\% dan CO2 yang memiliki kisaran nilai 3,27-35,20\% serta nilai kalori yang berkisar antara 7.434-7.833 kal/gr. Merujuk dari pendapat Rice dan hasil penelitian tersebut, lapisan batubara $B$ dan $C$ di lubang bor AD-01 daerah Ombilin, Kota Sawahlunto, Provinsi Sumatera Barat dapat dikategorikan memiliki potensi gas metana yang cukup baik untuk dikembangkan.

Berdasarkan hasil plot antara kandungan zat terbang dan belerang terhadap terhadap kedalaman terlihat bahwa kadar atau kandungan zat terbang dan belerang memiliki nilai yang cenderung semakin membesar dengan kedalaman lapisan batubara yang semakin bertambah (Gambar 4).

Namun sebaliknya, berdasarkan hasil plot antara kandungan karbon tertambat dan abu menunjukkan bahwa kandungan karbon tertambat dan abu semakin mengecil dengan kedalaman lapisan batubara yang semakin bertambah (Gambar 5).

Plot antara nilai kalori batubara dengan kedalaman menunjukkan semakin dalam keterdapatan batubara, nilai kalori batubara semakin besar. Namun hasil ini berbeda dengan kandungan gas metana batubara yang terdapat pada kedua lapisan batubara tersebut dimana pada batubara Lapisan B memiliki kandungan gas metana yang lebih besar dibandingkan Lapisan C (Gambar 6 dan 7).

Berdasarkan hasil ketiga plot tersebut dapat diperkirakan adanya faktor korelasi antara hasil analisis proksimat terhadap jumlah kandungan gas metana batubara yang terdapat pada kedua lapisan batubara tersebut.

Faktor yang mempengaruhi gas metana di daerah penelitian:

Pertama kandungan zat terbang dan belerang dimana nilai kandungan kedua komponen tersebut pada batubara Lapisan B memilki nilai yang lebih kecil dibandingkan dengan Lapisan C sehingga dimungkinkan memperkecil jumlah kandungan gas metana di Lapisan C.

Kedua kandungan karbon tertambat dan abu dimana hasil analisis proksimat menunjukkan nilai kedua komponen tersebut pada batubara Lapisan B memliki nilai yang lebih besar dibandingkan dengan Lapisan C sehingga dimungkinkan memperbesar jumlah kandungan gas metana di Lapisan B.

Ketiga nilai kalori dimana nilai kalori di batubara Lapisan B lebih kecil dibandingkan dengan Lapisan C sehingga dimungkinkan pula memperkecil jumlah kandungan gas metana batubara di Lapisan C. 


\section{MAKALAH ILMIAH}
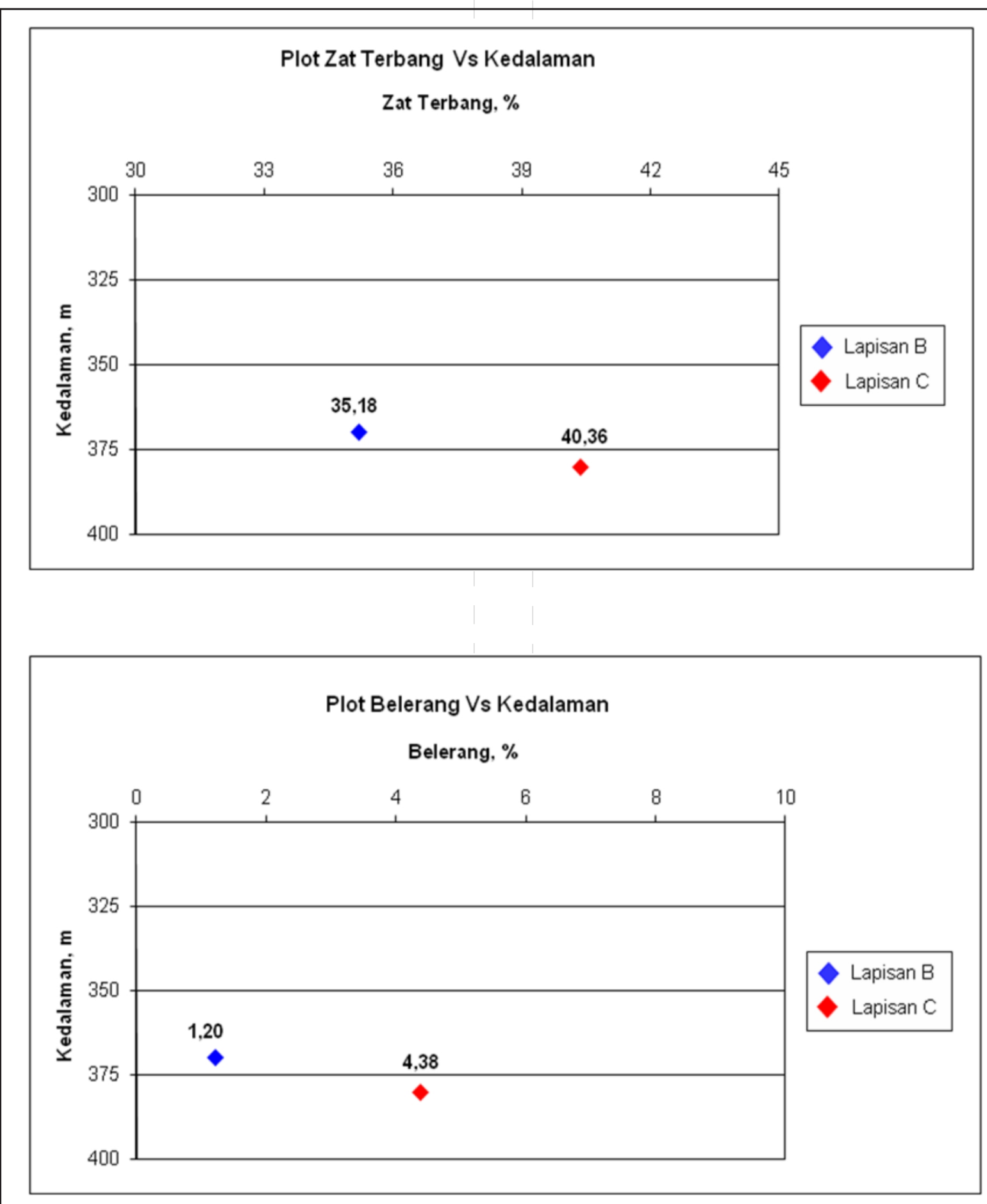

Gambar 4. Korelasi antara zat terbang dan belerang terhadap kedalaman 


\section{MAKALAH ILMIAH}

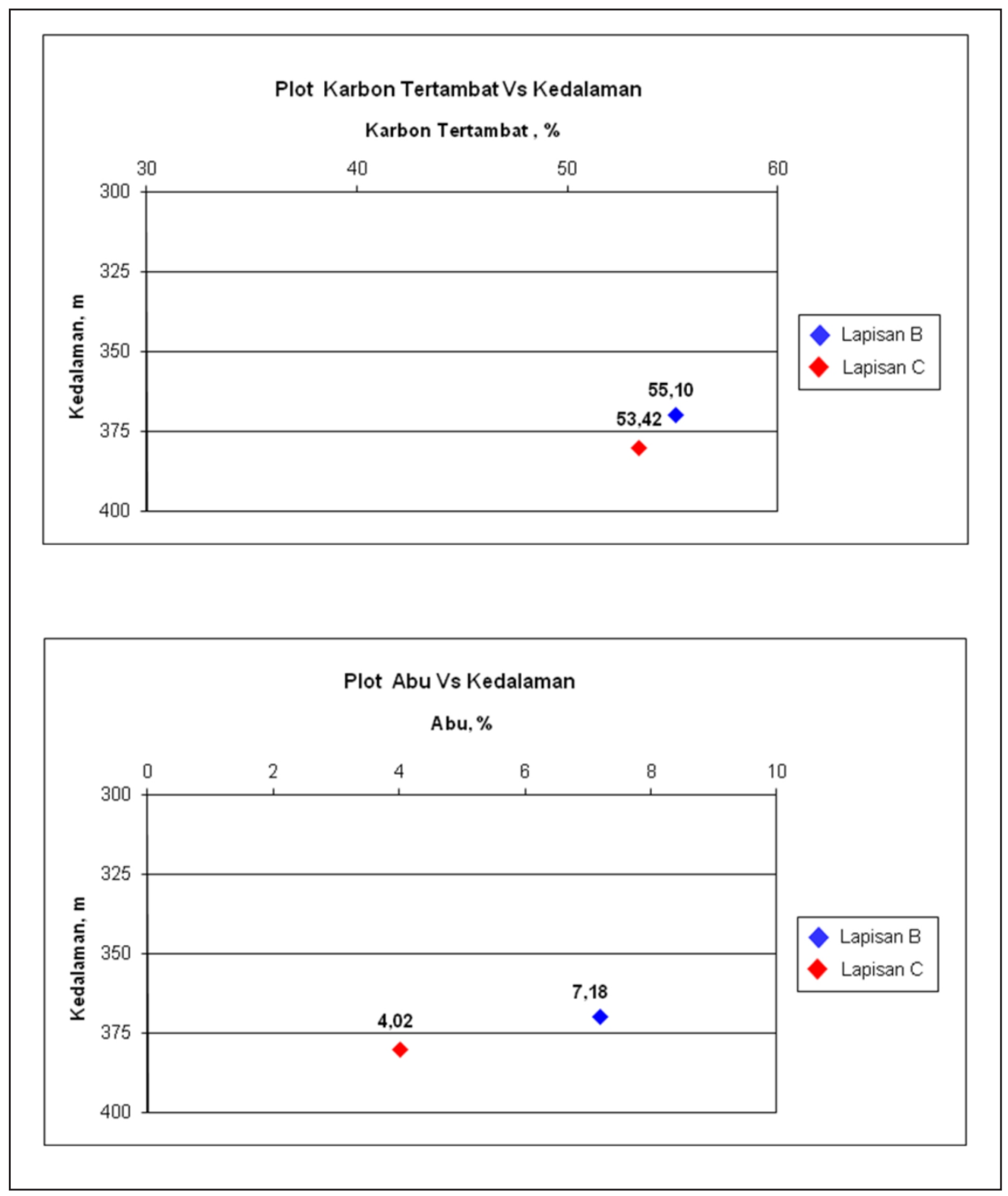

Gambar 5. Korelasi antara karbon tertambat dan abu terhadap kedalaman 


\section{MAKALAH ILMIAH}

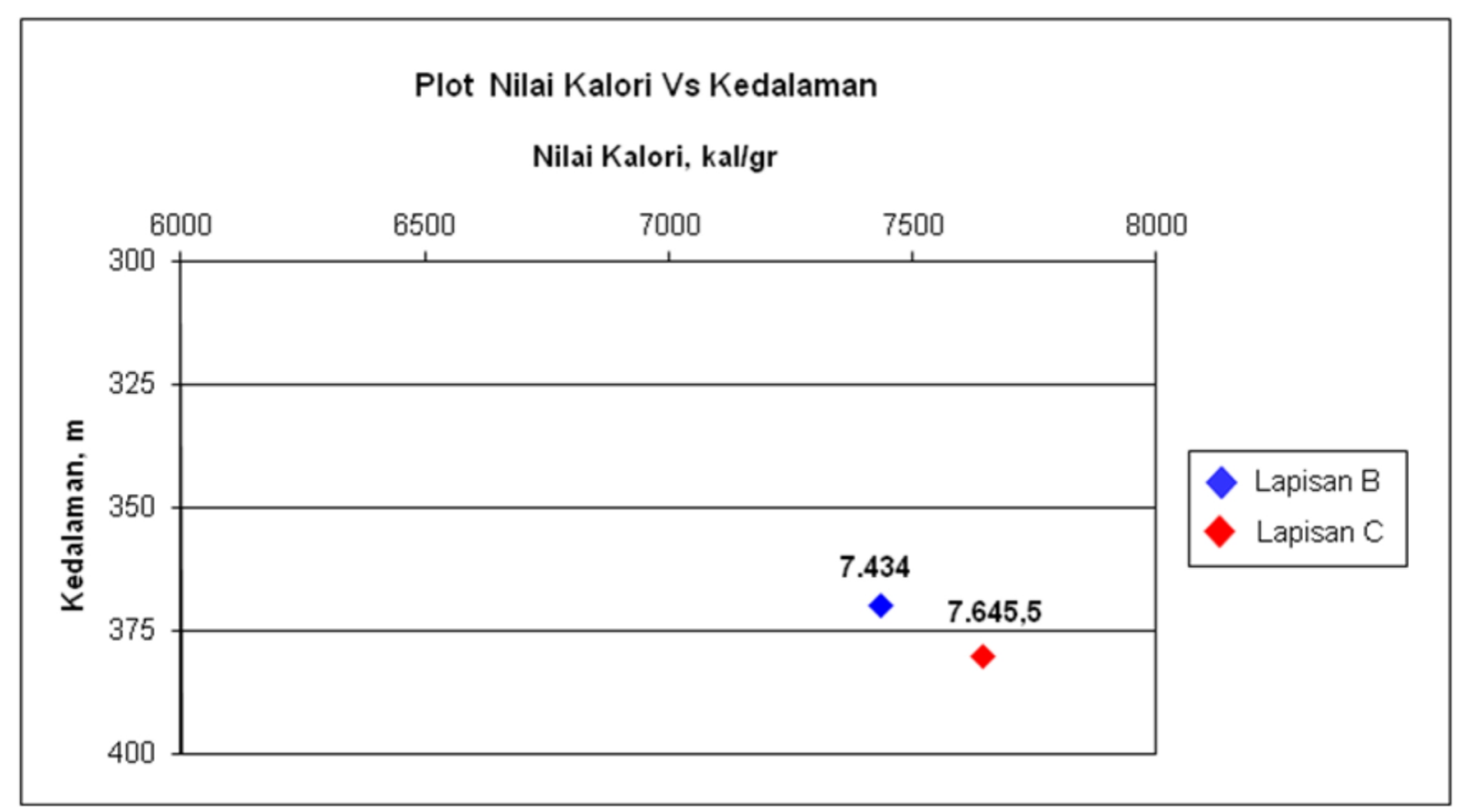

Gambar 6. Korelasi antara nilai kalori terhadap kedalaman

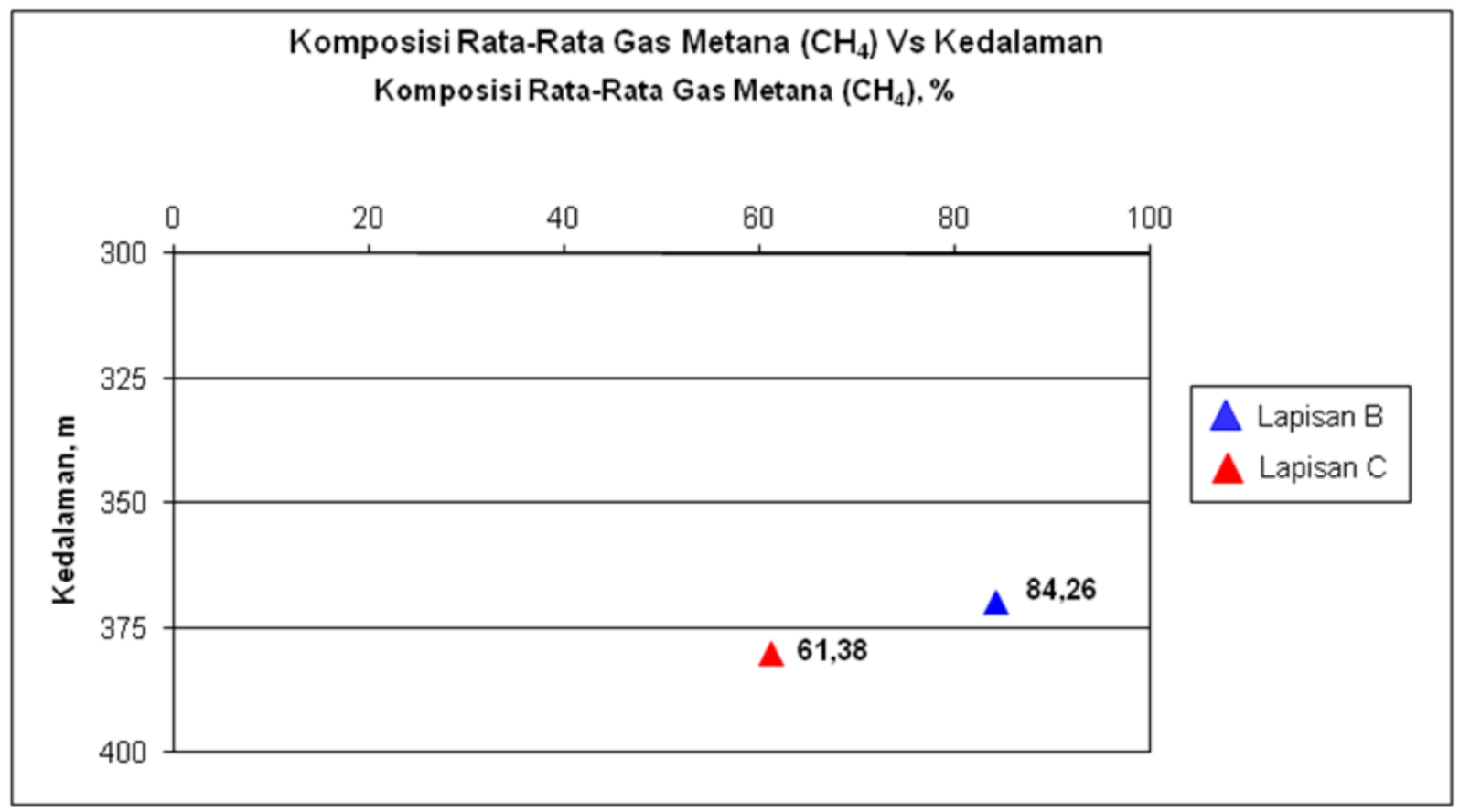

Gambar 7. Korelasi antara komposisi gas metana batubara terhadap kedalaman 


\section{KESIMPULAN}

Batubara Lapisan B dengan kedalaman antara 369,75-371,50 meter memiliki ketebalan 1,75 meter dan kandungan gas metana $84,26 \%$. Sedangkan Lapisan C dengan kedalaman antara 380,24-390,80 meter memiliki ketebalan 13,56 meter dan kandungan gas metana $61,38 \%$.

Berdasarkan hasil analisis proksimat batubara di daerah penelitian memiliki nilai kalori 7.434 $7.833 \mathrm{kal} / \mathrm{gr}$ dan termasuk kedalam golongan High Volatile Bituminus C-A.

Dari hasil analisis komposisi gas menunjukkan bahwa kandungan gas metana batubara Lapisan B lebih besar dibandingkan Lapisan C yang memiliki ketebalan dan keterdapatan lapisan batubara yang lebih tebal dan lebih dalam. Hal ini diperkirakan karena adanya beberapa faktor dari hasil analisis proksimat yaitu faktor kandungan zat terbang, belerang dan nilai kalori pada batubara Lapisan $B$ lebih kecil dibandingkan Lapisan C. Kemudian faktor kandungan karbon tertambat dan abu pada batubara Lapisan B lebih besar dibandingkan Lapisan C.

Perlu dicatat bahwa penelitian di lokasi pemboran AD-01 hanya berdasarkan pada jumlah sampel yang sedikit. Untuk penelitian lebih lanjut, disarankan agar dapat dilakukan perbandingan komposisi gas terhadap kadar zat terbang, karbon tertambat, abu, belerang dan nilai kalori dengan jumlah conto batubara yang lebih banyak.

\section{UCAPAN TERIMAKASIH}

Penulis mengucapkan terima kasih kepada Ir. Deddy Amarullah dan Ir. Asep Suryana yang telah memberikan dukungan, arahan dan bimbingan sehingga penulis dapat menyelesaikan tulisan ini dengan baik.

\section{DAFTAR PUSTAKA}

ASTM, 2004. Annual Book of ASTM Standards, Vol. 05.06. American Society for Testing and Materials, West Conshohocken, PA

Febriantara, 2011., Batubara, (online), http://febriantara.wordpress.com/2009/03/18/batubara/, diakses tanggal 13 Oktober 2011

Flores, R.M., 2008. Coalbed Methane: Gas of the Past, Present, and Future. U.S. Geological Survey

Koesoemadinata R. P., \& Matasak Th., 1981. Stratigraphy and Sedimentation Ombilin Basin Central Sumatera (West Sumatera Province), Proceeding, IPA, Tenth Annual Convention.

Koning T.,1985., Petroleum Geology of the Ombilin Intermontane Basin. Indonesian Petroleum Association. 14th annual convention.

Pusat Sumber Daya Geologi (Tim Pemboran PSDG, 2009)., Laporan Pemboran Dalam Batubara Di Cekungan Ombilin, Kota Sawahlunto, Provinsi Sumatera Barat. Pusat Bandung.

Sumber Daya Geologi, Badan Geologi. Kementerian Energi Dan Sumber Daya Mineral,

Rice, D.D., 1993. Composition and Origins of Coalbed Gas. In: Law, B.E., and Rice, D.D. (Eds.), Hydrocarbons from Coal. American Association of Petroleum Geologists Studies in Geology 38, 159184.

Silitonga P.H. \& Kastowo, 1995. Peta Geologi Lembar Solok, Sumatera, Peta Geologi bersistem Sumatera, PPPG, Bandung.

Speight, J. G., 2005. Handbook of coal analysis. John Wiley \& Sons, Inc., Hoboken, New Jersey. United States of America.

\section{USGS, 2000. Presentation Slide Methode Gas Analysis, Colorado, USA}

Sigit A.W., 2011., Kandungan Gas Metana Batubara Daerah Nibung, Kabupaten Musi Rawas, Provinsi Sumatera Selatan., Buletin Sumber Daya Geologi Volume 6. No 1 2011., Pusat Sumber Daya Geologi, Badan Geologi, Kementerian Energi dan Sumber Daya Mineral, Bandung.

Wikipedia, 2011., Metana, (online), http://www.id.wikipedia.org/wiki/Metana.html, diakses tanggal 16 Juni 2011. 